\title{
Capacity Configuration Optimization of Micro-grid System based on Quantum Particle Swarm Algorithm
}

\author{
ZHANG Yuqiong ${ }^{1}$, CHEN Ziwei ${ }^{1}$, SHAO Zhifang ${ }^{2 *}$, ZHAO Qiang ${ }^{1}$, and HAN Chuyin ${ }^{3}$ \\ ${ }^{1}$ China Electric Power Research Institute, Beijing, 100192 \\ ${ }^{2}$ School of Information Management \& Engineering, Shanghai University of Finance and Economics \\ ${ }^{3}$ State Key Laboratory of Power Systems, Department of Energy and Power Engineering, Tsinghua-BP Clean Energy Research and \\ Education Centre, Tsinghua University, Beijing, 100084, China
}

\begin{abstract}
The optimized configuration of wind/photovoltaic/storage micro-grid system capacity can realize multi-energy complementation and improve the stability and economy of grid-connected operation of power generation units. In this paper, the capacity of each core component of the micro-grid system under different combination paths such as Wind-PV power generation, battery energy storage, hydrogen production by electrolysis, and fuel cell power generation are optimized and economically analyzed. Taking the FCFF (Free Cash Flow of Firm) net present value maximization of the system running for 20 years as the objective function, considering the impact of energy shortage rate and dynamic electricity price, an operation research optimization model is established and intelligent algorithms are used to solve the model. The model can flexibly realize capacity optimization under different micro-grid combination paths, and it can prevent the solution result from falling into the local optimum through the design of quantum particle swarm algorithm. We analyzed the optimization results in terms of economic benefits, social benefits, and environmental benefits, and further analyzed the annual power generation status of the system and the operation status of the electrolysis hydrogen production system. The calculation example shows that under the current technical conditions, the micro-grid system composed of wind and solar power generation, electrochemical energy storage, and hydrogen production by electrolysis has better economic, social and environmental benefits than other models.
\end{abstract}

\section{Introduction}

The vigorous development of energy storage technology is of great significance to promote renewable energy consumption, enhance the flexibility of power system and promote the wide application of micro-grid technology. By comprehensively considering the characteristics of various equipment and energy storage technology of micro-grid, the energy storage devices matching the storage type, service life, economic benefit, environmental benefit and capacity are selected and reflected in the operation optimization objectives and constraints of micro-grid. Therefore, it is helpful to realize the accurate and flexible control of the system, improve the utilization rate of renewable energy and the overall operation efficiency of micro-grid [1]. The existing research is generally based on a certain energy storage path (such as wind-PV-mechanical energy storage, windPV-electrochemical energy storage, wind-PV-hydrogen energy storage, etc.) to study the capacity allocation optimization problem under this path. For example, Amrollahi et al. [2] established a capacity optimization configuration model for pumped storage-battery composite energy storage system. Deng et al. [3] takes the lowest annual investment cost of wind-light-battery micro-grid as the objective function, and establishes the optimal allocation model of wind/photovoltaic/storage micro-grid. Yang et al. [4] applies battery and supercapacitor hybrid energy storage to the grid-connected wind and solar hybrid power generation system, and optimizes the configuration of the micro-grid system capacity. Due to the clean and pollution-free characteristics of hydrogen, the wind-photoelectric coupling hydrogen energy storage system is also a research hotspot[5]. For example, F.Grüger et al. [6] uses Aspen Plus 9.0 software and EES software to simulate and analyze a wind-solar coupling hydrogen storage system. H. Ishaq et al. [7] proposed a wind power hydrogen production system based on wind power-hydrogen energy storage technology to improve the capacity of abandoning electricity. Men et al. [8] studied the energy interconnection micro-grid multi-energy complementary system under the gas-electricity-heat hybrid energy storage mode. Different from the above research, the wind/photovoltaic/storage micro-grid model established in this paper can study the capacity configuration optimization of wind photovoltaic, electrolyzer, storage battery, fuel cell and other components under multiple combination paths. This paper also conducts a quantitative 
analysis on the economics under the optimal capacity configuration, so as to determine the optimal micro-grid system composition and the most economical capacity configuration that matches the natural resource conditions of a certain place.

In terms of solving capacity configuration optimization model, in order to improve the solving efficiency, the research on model solving based on artificial intelligence algorithm is gradually increasing. For example, Sanchez et al. [9] analyzed the economics and capacity allocation of the solar-hydrogen combination in northeastern Mexico and adopted particle swarms algorithm (Particle Swarm Optimization, PSO) for solving. Compared with Differential Evolution, the PSO algorithm converges faster. Khiareddine et al. [10] studied four optimization algorithms, including PSO, tabu-search, simulated annealing and harmony search, as well as their improved algorithms, and used the improved algorithm to search for the optimal capacity configuration of the microgrid system, and proved that the improved PSO algorithm had better solving performance. Pablo et al. [11] used particle swarm algorithm to optimize wind and solar hybrid power generation systems with multiple objectives, and used weighting methods to solve the problem of "minimizing energy storage system operating costs", "maximizing energy storage system efficiency" and "optimizing equipment service life" "The optimization problem of three indicators that are ebb and flow. Zhao et al. [12] introduced a demand-side response model to optimize the energy storage configuration of the optical storage micro-grid, and solved the demand-side response process with a combined particle swarm algorithm.

Some scholars [13] [14] found that under the same conditions, the particle swarm algorithm has better search capabilities, stronger robustness, and faster convergence speed for solving the capacity configuration optimization problem of the wind and solar system. However, due to the lack of randomness in the particle position change of the PSO algorithm, it is easy to fall into the trap of local optimization. Quantum Particle Swarm Optimization (QPSO) cancels the movement direction properties of particles and introduces the concept of quantum clouds, thereby increasing the randomness of particle positions and improving the algorithm's global search capabilities. Based on this, this paper uses the QPSO algorithm to solve the multi-path capacity configuration optimization model.

In terms of economic evaluation, this paper uses FCFF (Free Cash Flow of Firm) discount to calculate the net present value of the project. FCFF model considers that the value of the company is the expected cash flow of the company, which is discounted according to the company's cost of capital. The company's cost of capital is measured by WACC (Weighted Average Cost of Capital). Different from the traditional measurement of capital cost by return on investment or interest rate, the weighted average cost of capital is more in line with the market reality.

In addition, existing studies rarely consider the impact of grid electricity prices. With the advancement of electricity market reform in China, due to the dynamic change of electricity price, when to purchase and sell electricity from the grid will have an impact on the economy of the system. Therefore, this paper uses dynamic electricity prices for analysis, which makes the model more practical.

\section{Description of wind/ photovoltaic/ storage micro-grid system}

\subsection{Overall system architecture}

The system model of wind/photovoltaic/storage microgrid system is mainly composed of the following parts:

(1) Wind power and photovoltaic power generation system: as the power source of the system, they are affected by geographical location and weather factors.

(2) User load: On the power consumption side of the wind and solar storage micro-grid system, the micro-grid system provides power to meet user load.

(3) Electrochemical energy storage system: it stores part of the excess electricity and provides electricity when wind power and photovoltaic power are insufficient, so as to meet the electricity demand as much as possible and improve the reliability of the power system.

(4) Electrolysis hydrogen production system: Use part of the excess electricity to electrolyze water to produce hydrogen, and store the produced hydrogen in fuel cells or sell it externally.

(5) Fuel cell power generation system: convert hydrogen energy into electric energy to supplement the missing power when the system output power is insufficient.

(6) Inverter and other auxiliary facilities: the inverter can realize the mutual conversion of $\mathrm{DC}$ and $\mathrm{AC}$, and other auxiliary facilities include compressor, etc.

(7) Power grid: when the micro-grid system cannot meet the user's load, the power grid serves as an external power source, and the micro-grid system can purchase electricity from the grid to meet the user's load; when the excess power cannot be consumed, the grid can accept the micro-grid power as the power receiver.

The main frame is shown in Fig.1.

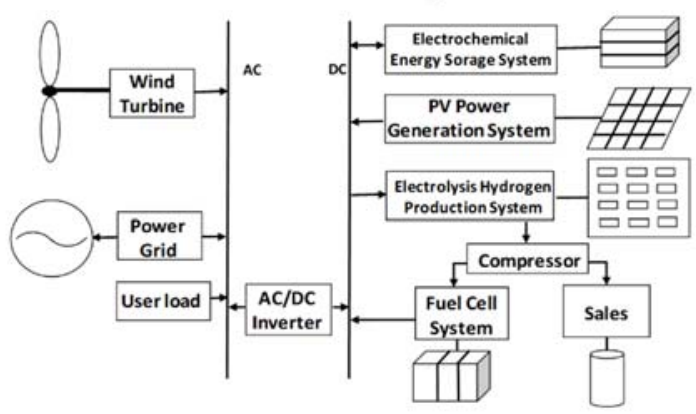

Fig.1. Schematic diagram of Wind-PV-Storage micro-grid system

\subsection{Output model of main modules}

The main modules of wind-photovoltaic-storage microgrid system include components such as wind turbines, photovoltaic battery packs, electrolyzers, storage batteries and fuel cells. Among them, the calculation process of the relationship between the output power of the wind turbine 
and the wind speed can be found in [15], and the output model of the photovoltaic battery from the regional solar radiation intensity can be seen in [2]. Referring to kinetic power battery model, the electrochemical energy storage system divides the remaining capacity of battery into non bound energy that can be released immediately and bound energy that cannot be released immediately, so the charge and discharge power of battery is expressed as a function of the remaining energy of battery. The basic calculation formula is shown in [8]. The core component of the electrolysis hydrogen production system is the electrolysis cell. This paper assumes that the rate of hydrogen production in the electrolysis cell is linearly related to its input power and the calculation formula is shown in [16]. Hydrogen fuel cell is a device that converts chemical energy into electrical energy without a combustion process. This paper assumes that fuel cells are used to supplement the missing power of wind turbines, photovoltaic cells, and storage batteries and the calculation process is described in [17].

\subsection{Working mode of wind-photovoltaic-storage micro-grid}

In this paper, the basic principle of the wind-photovoltaicstorage micro-grid system model is dynamic energystorage and timely release. The model uses hourly wind data to obtain the hourly power of the wind turbine, and hourly light data to obtain the hourly power of photovoltaic cells, and compares the wind and solar power generation with the hourly user load. When the electricity generated is greater than the user's load, the priority of the operation from high to low is: charging the battery; electrolyzing the electrolyzer, and storing the hydrogen produced in the fuel cell hydrogen storage tank; storing the produced hydrogen in the high-pressure hydrogen storage tank for waiting sale; the remaining power is sold to the grid. When the generated electricity is less than the user's load, the operation priority from high to low is: using battery power supply, using fuel cell power supply; purchasing power from the grid.

The detailed working mode of wind-PV-storage micro-grid is shown in Fig.2.

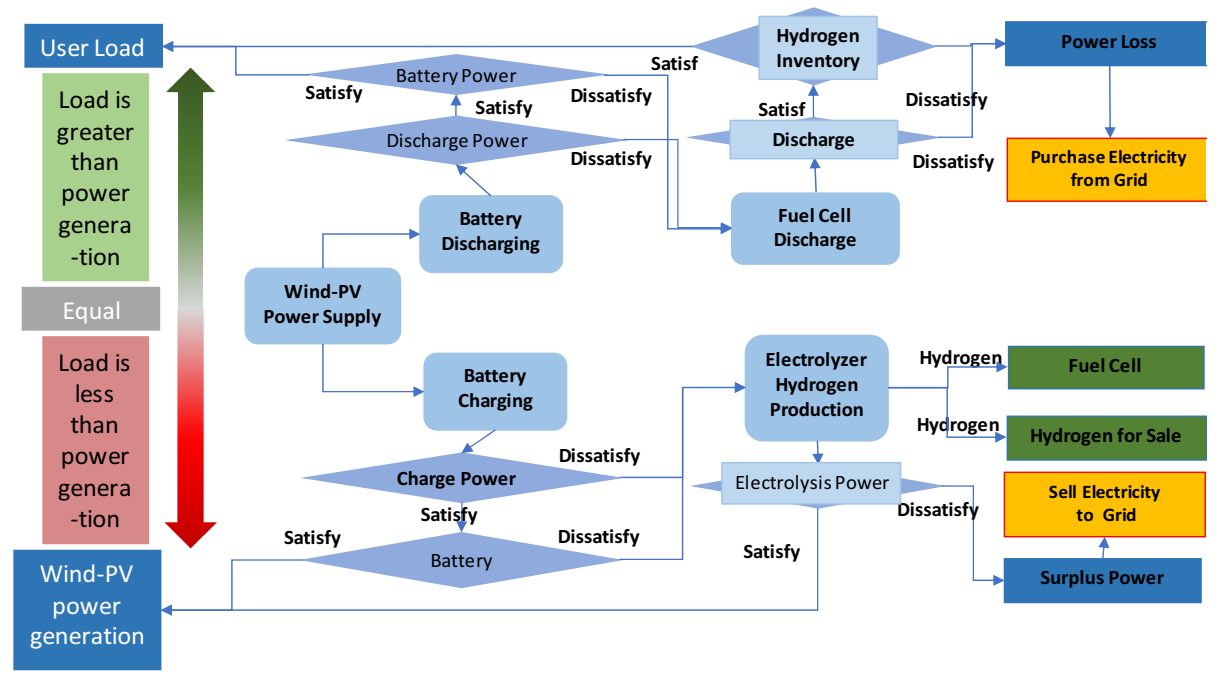

Fig.2. Working mode of wind-PV-storage micro-grid

\section{Capacity optimization model}

\subsection{Objective function}

In this paper, the net present value (NPV) of the project is used as the objective function, and the maximization of the net present value of the project for 20 years is the model optimization objective; at the same time, the energy shortage rate of the system is restricted as a constraint condition.

The net present value of the project is calculated using the FCFF discount. The FCFF model believes that the company's value is the expected cash flow of the company and discounted according to the company's cost of capital. The company's cost of capital is measured by WACC (Weighted Average Cost of Capital).

$$
W A C C=\frac{D}{V} r_{D}\left(1-T_{c}\right)+\frac{E}{V} r_{E}^{l}
$$

In formula (1), $D$ is the company's liabilities; $V$ is the company's total assets; $E$ is the company's owner's equity; $V=D+E ; r_{D}$ is the cost of debt capital, and $T_{c}$ is the corporate income tax rate.

$$
r_{E}^{l}=r_{f}+\beta_{E}^{l}\left(E\left(r_{m}\right)-r_{f}\right)
$$

In formula (2), $r_{E}^{l}$ is determined by leveraged equity $\beta_{E}^{l}$, risk-free interest rate ${ }_{f}$, and market expected rate of return $E\left(r_{m}\right)$.

$$
\beta_{E}^{l}=\beta_{E}^{u}+\left(\beta_{E}^{u}-\beta_{D}\right) \frac{D}{E}
$$

In formula (3), $\beta_{E}^{l}$ is determined by unlevered equity $\beta_{E}^{u}$, debt cost $\beta_{D}$, income tax rate, company liabilities $D$, and company equity $E$.

$$
\begin{gathered}
F C F F=E B I T\left(1-T_{c}\right)+D \& A- \\
C A P X-N W C
\end{gathered}
$$

In formula (4), $F C F F$ is free cash flow; $E B I T$ is 
profit before interest and tax; $D \& A$ is depreciation and amortization; $C A P X$ is capital expenditure, and $N W C$ is change in net working capital.

$$
\begin{gathered}
E B I T=\operatorname{sales}\left(1-T_{v a t}\right)+C_{m} * T_{\text {vat }}- \\
= \\
\cos t-S \& M-D \& A
\end{gathered}
$$

In this paper, it is assumed that the company does not consider the profit and loss of changes in fair value, does not make other investments, and does not have nonoperating expenses. Therefore, in formula (5), EBIT is the sales revenue minus the production cost $\cos t$, sales and management expenses $S \& M$. sales is the sales revenue of electricity and hydrogen oxygen, and $T_{\text {vat }}$ is the value-added tax rate.

$$
\begin{gathered}
C P T_{0}=C P T_{p v}+C P T_{W T}+C P T_{E}+ \\
C P T_{B}+C P T_{F C}+C P T_{A E}
\end{gathered}
$$

In formula (6), $C P T_{p v}$ is the cost of photovoltaic cells; $C P T_{W T}$ is the cost of wind turbines; $C P T_{E}$ is the cost of electrolyzers; $C P T_{B}$ is the cost of batteries; $C P T_{F C}$ is the cost of fuel cells, and $C P T_{A E}$ is the cost of auxiliary equipment.

$$
\begin{gathered}
\text { sales }=\sum_{t=1}^{T}\left(\left(P_{l}(t) \gamma_{l}-D P S(t)\right) \times \operatorname{Pr} \text { ice }_{e}(t)+\right. \\
\left.E P G(t) \times \operatorname{Pr} i c e_{s}(t)\right) \Delta t+N_{h s} \times \operatorname{Pr} i c e_{h} \\
C_{m}=N_{h s} \times \eta_{w h} \times \operatorname{Pr} i c e_{w}+ \\
\sum_{t=1}^{T} D P S(t) \times \operatorname{Pr} \text { ice }_{b}(t) \times \Delta t
\end{gathered}
$$

This paper considers the impact of dynamic electricity prices on net present value. In formula (7) (8), $N_{h s}$ is the annual hydrogen production; $\operatorname{Pr} i_{h}$ is the price per cubic meter of hydrogen in a standard state, and $T$ is 8760 hours. $D P S(t)$ is the unsatisfied user load at time; $E P G(t)$ is the power that the system cannot absorb at time. Both will be defined in detail below. $\operatorname{Pr} i c e_{e}(t)$ is the price of electricity sold to users at time $t$, and $\operatorname{Pr}_{\text {ice }}(t)$ is the price of electricity sold to the grid at time ${ }^{t} . \eta_{w h}$ is the volume of purified water consumed to produce a standard cubic meter of hydrogen per unit volume; Price $e_{w}$ is the price of purified water per unit volume, and $\operatorname{Pr} i c e_{b}(t)$ is the price of electricity purchased from the grid at time $t$.

From the above formulas, the net present value of the project can be obtained as follows:

$$
N P V=\sum_{t=1}^{T} \frac{F C F F}{(1+W A C C)^{t}}-C P T_{0}+R V
$$

In formula (9), $N P V$ is the net present value of the project; $C P T_{0}$ is the initial investment cost, and $R V$ is the residual value of the equipment.

\subsection{Constraint condition}

While considering the economics of the project, this paper also adds the stability of the system and the utilization rate of new energy to the evaluation system.

$$
\begin{array}{r}
D P S(t)=P_{l}(t) \gamma_{l}-\left[P_{w t}(t)+P_{p v}(t)+\right. \\
\left.P_{B, d}(t) \times \eta_{b, d}+P_{F C}(t) \times \eta_{F C}\right]
\end{array}
$$

$\operatorname{DPS}(t)$ is the power value that the user load exceeds the system output at time $t$. In the case of grid connection, the shortage of electricity can be made up by purchasing electricity from the grid. $\gamma_{l}$ is the proportion of the output of the micro-grid system, which can be determined according to the country's development goals on the proportion of renewable energy.

$$
D P S P=\frac{\sum_{t=1}^{T} D P S(t) \Delta t}{\sum_{t=1}^{T} P_{l}(t) \gamma_{l} \Delta t}
$$

$D P S P$ is the energy shortage rate, which measures the rate that the user's load is not met.

$$
\begin{gathered}
E P G(t)=P_{w t}(t)+P_{p v}(t)-\left[P_{l}(t) \gamma_{l}+\right. \\
\left.P_{B, c}(t) / \eta_{b, c}+P_{E}(t) \times \eta_{E}\right]
\end{gathered}
$$

$E P G(t)$ is the power generated by wind turbines and solar cells that exceeds the power used at time $t$.

$$
A R=\frac{\sum_{t=1}^{T} E P G(t) \Delta t}{\sum_{t=1}^{T}\left(P_{w t}(t)+P_{p v}(t)\right) \Delta t}
$$

$A R_{\text {(abandoned rate) measures the abandonment rate. }}$ In the case of grid connection, the abandoned power of the system will be sold to the grid.

In summary, the model constraints are as follows:

(1) Constraints on energy shortage rate

$$
D P S P \leq 10 \%
$$

During the operation period, the energy shortage rate shall be counted once a year, which shall not exceed $10 \%$ each time, that is, the annual accumulated unmet user load shall not exceed $10 \%$ of the total user load that the system shall meet.

\section{(2) Constraint on curtailment rate}

$$
A R \leq 15 \%
$$

This paper assumes that in the case of grid connection, the micro-grid system can sell the abandoned power that cannot be absorbed to the grid, but in order to achieve the balance of supply and demand within the system as far as possible, and considering that the sold power has great volatility and intermittence, which will impact on the grid and increase the peak shaving cost of the grid, the constraint of abandoned power rate is set to prevent the system from selling too much power that exceeds the grid's absorption capacity.

(3) Constraints on charging and discharging power of battery packs

$$
\begin{aligned}
& P_{B, d}(t) \leq P_{B, d \max }(t) \\
& P_{B, c}(t) \leq P_{B, c \text { max }}(t)
\end{aligned}
$$


$P_{B, d}(t)$ and $P_{B, c}(t)$ are the actual discharge power and charging power of the battery respectively. In actual operation, the battery at time ${ }^{t}$ can only discharge and charge by $P_{B, d \max }(t)$ and $P_{B, c \max }(t)$ respectively.

(4) Depth constraint of battery discharge

$$
\begin{gathered}
\left(1-\mathrm{DOD}_{\max }\right) \leq S O C(t) \leq 1 \\
\operatorname{SOC}(t) \leq \frac{E_{B}(t)}{E_{B \max }}=\operatorname{SOC}(t-1)(1-\sigma)+ \\
P_{B, c}(t) * \eta_{b, c}-\frac{P_{B, d}(t)}{\eta_{b, d}}
\end{gathered}
$$

$\mathrm{DOD}_{\text {max }}$ is the discharge depth of the battery, $S O C(t)$ is the state of charge of the battery, and $\sigma$ is the self discharge ratio.

(5) Constraints on inverter power

$$
\begin{aligned}
P_{\text {inverter }} \geq \max \left\{P_{B, c}(t)+P_{E}(t),\right. \\
\left.P_{B, d}(t)+P_{p v}(t)+P_{F C}(t)\right\}
\end{aligned}
$$

$P_{\text {inverter }}$ is the power of the inverter, which should always be greater than the conversion power required by the system.

(6) Constraints on the proportion of renewable energy

$$
\mathrm{RER}=\frac{\sum_{t=1}^{T}\left(p_{l}(t) r_{l}-D P S(t)\right) \Delta t}{\sum_{t=1}^{T} p_{l}(t) \Delta t} \geq r_{r}
$$

RER (renewable energy ratio) is the proportion of renewable energy. According to the national development strategy, renewable energy should reach a certain proportion in the power system, and $r_{r}$ is the target proportion.

(7) Storage constraints on hydrogen storage tanks

$$
N_{h}(t) \leq N_{h}^{\max }
$$

In this paper, only the storage of hydrogen for fuel cell power generation is considered, and other hydrogen is sold immediately at the market price, so only the constraints of hydrogen storage tank of fuel cell are considered. $N_{h}(t)$ is the hydrogen content in the fuel cell hydrogen storage tank at time ${ }^{t}$, and $N_{h}^{\max }$ is the capacity of the fuel cell hydrogen storage tank.

\section{Algorithm design}

This paper uses the QPSO algorithm to solve the optimization model established above. QPSO is improved on the basis of PSO and has the following characteristics:

(1) The algorithm converges globally and can jump out of the local convergence point.

(2) The particle collaborative search ability in the algorithm is stronger.

(3) The algorithm needs to set fewer parameters, is easy to set, and has better robustness.

QPSO cancels the velocity attribute of particles and introduces the concept of quantum cloud. It assumes that particles can appear at any point in the search space, and the probability of occurrence is determined by a certain probability distribution function. The iterative updating process of particles is as follows:

$$
\begin{gathered}
m_{\text {best }}=\frac{1}{m} \sum_{i=1}^{m} P_{i}(t) \\
P_{i}(t+1)=\Psi P_{i}(t)+(1-\Psi) P_{g}(t) \\
X_{i}(t+1)=P_{i}(t+1) \pm \\
\lambda\left\|m_{\text {best }}-X_{i}(t)\right\| \ln \left(\frac{1}{u}\right)
\end{gathered}
$$

In formula (23-25), $m$ is the number of particles, and a total of $m$ capacity configuration schemes are evaluated in one iteration of the algorithm; $X_{i}(t)$ is the position of particle $i$ in the $t$ th iteration, that is, the capacity configuration scheme of particle $i ; P_{i}(t)$ is the best position experienced by particle $i$ in the previous $t$ iterations; $m_{\text {best }}$ is the average of the best positions experienced by all particles; $P_{g}(t)$ is the optimal position experienced by all particles; $\Psi$ and $u$ is a random variable with $(0,1)$ distribution, and \pm means that the probability of taking positive or negative is $1 / 2 ; \lambda$ is the only parameter that needs to be set in advance.

The main steps are as follows:

Step 1: determine the length and range of particles, initialize the position of particles, that is, initialize $m$ capacity configuration schemes.

Step 2: calculate the fitness of each particle, that is, the fitness of each capacity configuration scheme.

Step 3: determine the global optimal scheme and the individual optimal scheme of each particle.

Step 4: calculate $m_{\text {best }}$ and $P_{i}(t+1)$, and update the position $X_{i}(t+1)$ of each particle.

Step 5: calculate the new fitness, update the global best scheme and individual best scheme.

Step 6: repeat steps 4 to 5 until the number of iterations is reached.

\section{Simulation analysis}

\subsection{Data processing and key equipment parameters}

\subsubsection{Power consumption data, wind speed data, solar radiation and air temperature data}

\section{(1) Electricity load}

The electricity load data comes from the hourly electricity load of a year in a certain place. The typical daily load line is shown in Fig.3. 


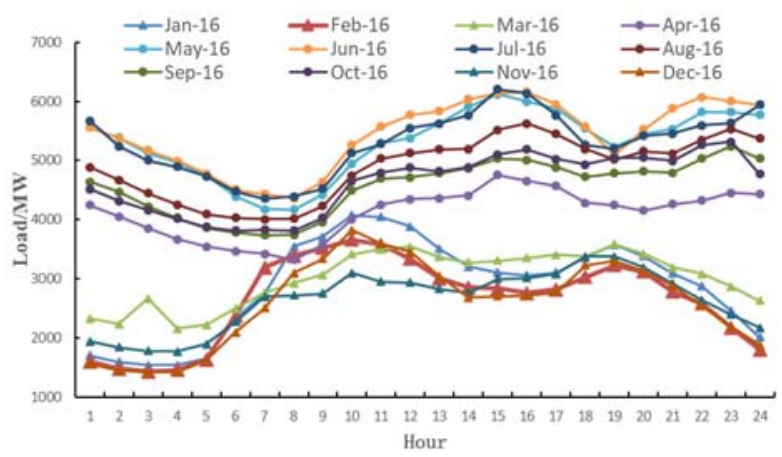

Fig.3. Typical load line

The above-mentioned load data is adjusted in equal proportions to obtain the power load data of the micro-grid, and the peak power load after adjustment is $11 \mathrm{Mw}$.

(2) Wind speed data

The wind speed data comes from the hourly wind speed data of a meteorological station in a year, which is located at $115^{\circ} 81^{\prime} \mathrm{E}$ and $37^{\circ} 13^{\prime} \mathrm{N}$. The annual timeaveraged wind speed is shown in Fig.4.

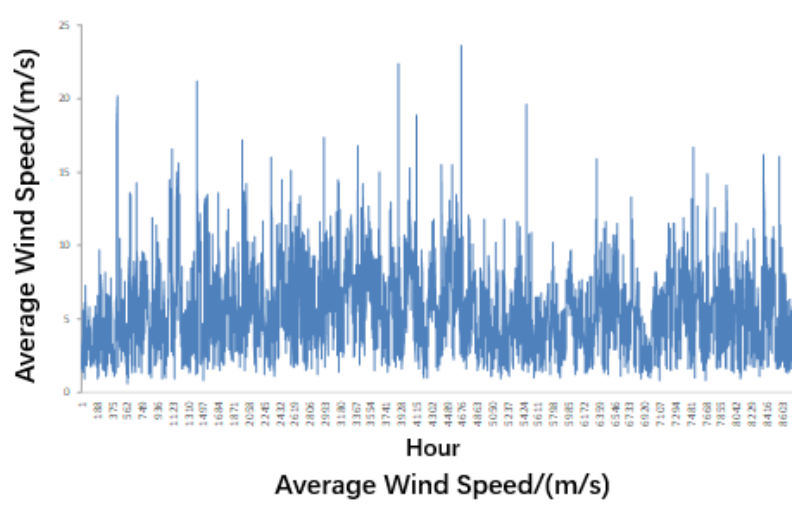

Fig.4. Time-averaged wind speed

\section{(3) Light and temperature data}

The time-averaged radiant intensity data of $115^{\circ} 81^{\prime}$ $\mathrm{E}$ and $37^{\circ} 13^{\prime} \mathrm{N}$ are obtained by Meteonorm, as shown in
Fig.5.

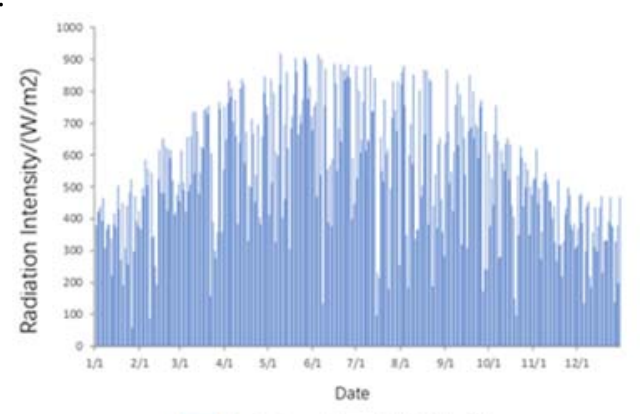

Radiation Intensity/(W/m2)

Fig.5. Time-averaged radiant intensity

The temperature data is shown in Figure 6.

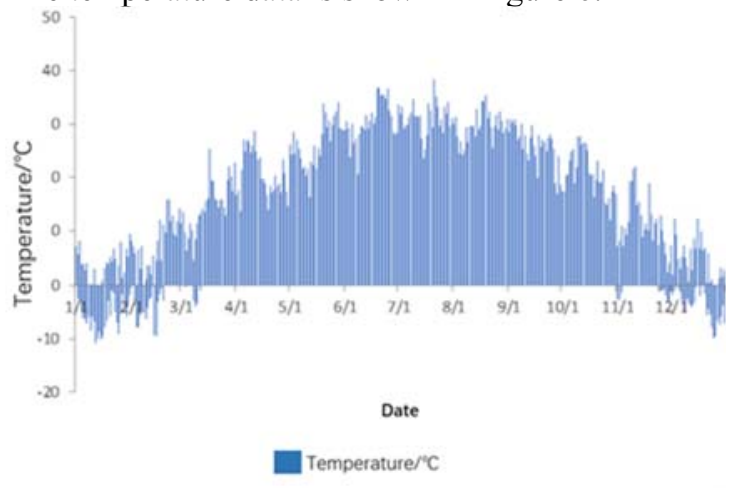

Fig.6. Average hourly temperature

\subsubsection{Equipment parameters}

The parameters of wind turbine equipment, photovoltaic power generation system, electrochemical energy storage system with lithium battery as the core, electrolytic hydrogen production system and hydrogen fuel cell power generation system with proton exchange membrane fuel cell as the core are shown in table 1-5.

Table1. Wind turbine equipment parameters

\begin{tabular}{ccccccc}
\hline rated power & $\begin{array}{c}\text { investment cost }(10000 \\
\text { yuan / set) }\end{array}$ & $\begin{array}{c}\text { life cycle } \\
(\text { year })\end{array}$ & $\begin{array}{c}\text { shaft height } \\
(\mathrm{m})\end{array}$ & $\begin{array}{c}\text { cut-in wind } \\
\text { speed } \\
(\mathrm{m} / \mathrm{s})\end{array}$ & $\begin{array}{c}\text { cut-out wind } \\
\text { speed } \\
(\mathrm{m} / \mathrm{s})\end{array}$ & $\begin{array}{c}\text { rated wind } \\
\text { speed }\end{array}$ \\
\hline $1.5 \mathrm{MW}$ & 450 & 30 & $80-100$ & 3 & 12 & 11 \\
\hline
\end{tabular}

Table2. Photovoltaic power system parameters

\begin{tabular}{cccc}
\hline $\begin{array}{c}\text { investment cost } \\
(\text { yuan } / \mathrm{KW})\end{array}$ & life cycle (year) & derating factor & $\begin{array}{c}\text { temperature power coefficient } \\
\left(\% /{ }^{\circ} \mathrm{C}\right)\end{array}$ \\
\hline 6000 & 30 & 0.7 & $-0.38-0.44($ Polysilicon $)$ \\
\hline
\end{tabular}

Table3. Electrochemical energy storage system parameters

\begin{tabular}{cccc}
\hline $\begin{array}{c}\text { investment cost } \\
(\text { yuan/KW })\end{array}$ & $\begin{array}{c}\text { life cycle } \\
\text { (year) }\end{array}$ & $\begin{array}{c}\text { capacity } \\
(\mathrm{KWh})\end{array}$ & $\begin{array}{c}\text { cycle } \\
\text { efficiency } \\
(\%)\end{array}$ \\
\hline 375 & 20 & $1 / 16$ & 95 \\
\hline 560 & 20 & $1 / 8$ & 95 \\
\hline 850 & 20 & $1 / 4$ & 95 \\
\hline 1270 & 20 & $1 / 2$ & 95 \\
\hline
\end{tabular}




\begin{tabular}{llll}
\hline 1900 & 20 & 1 & 95 \\
\hline 2850 & 20 & 2 & 95 \\
\hline 4280 & 20 & 4 & 95 \\
\hline
\end{tabular}

Table4. Electrolytic hydrogen production system parameters

\begin{tabular}{cccccc}
\hline $\begin{array}{c}\text { investment cost } \\
(10000 \text { yuan / set })\end{array}$ & $\begin{array}{c}\text { rated power } \\
(\mathrm{KW})\end{array}$ & $\begin{array}{c}\text { minimum hydrogen maximum hydrogen } \\
\text { production rate } \\
\left(\mathrm{Nm}^{3} / \mathrm{h}\right)\end{array}$ & $\begin{array}{c}\text { energy demand } \\
\text { production rate } \\
\left(\mathrm{Nm}^{3} / \mathrm{h}\right)\end{array}$ & $\begin{array}{c}\text { nominal } \\
\left(\mathrm{KWh} / \mathrm{Nm}^{3}\right)\end{array}$ & efficiency $(\%)$ \\
\hline 110 & 130 & 0 & 20 & 6.5 & 54.94 \\
\hline 150 & 280 & 0 & 50 & 5.6 & 63.77 \\
\hline 200 & 520 & 0 & 100 & 5.2 & 68.67 \\
\hline 230 & 780 & 0 & 150 & 5 & 71.42 \\
\hline 260 & 1000 & 0 & 200 & 5 & 71.42 \\
\hline 345 & 1500 & 0 & 300 & 5 & 71.42 \\
\hline 410 & 2000 & 0 & 400 & & 5.2 \\
\hline
\end{tabular}

Table5. Hydrogen fuel cell power generation system parameters

\begin{tabular}{ccc}
\hline $\begin{array}{c}\text { investment cost } \\
(\text { yuan } / \mathrm{KW})\end{array}$ & $\begin{array}{c}\text { life cycle } \\
\text { (year) }\end{array}$ & $\begin{array}{c}\text { energy efficiency } \\
(\%)\end{array}$ \\
\hline 5000 & 20 & 0.75 \\
\hline
\end{tabular}

The parameters of the inverter used in the calculation example are shown in Table 6. A single inverter can meet the requirements of $6 \mathrm{MW}$ wind turbine, $2 \mathrm{MW}$ photovoltaic cell and 5MW electrolytic cell.

Table6. Inverter parameters

\begin{tabular}{ccc}
\hline $\begin{array}{c}\text { investment cost } \\
(10000 \text { yuan / set) }\end{array}$ & $\begin{array}{c}\text { life cycle } \\
\text { (year) }\end{array}$ & $\begin{array}{c}\text { inverter } \\
\text { efficiency } \\
(\%)\end{array}$ \\
\hline 300 & 30 & 90 \\
\hline
\end{tabular}

The compressor parameters in the example are shown in Table 7.

Table7. Compressor parameters

\begin{tabular}{ccc}
\hline $\begin{array}{c}\text { investment cost } \\
(10000 \text { yuan } / \\
\text { set })\end{array}$ & $\begin{array}{c}\text { life cycle } \\
\text { (year) }\end{array}$ & $\begin{array}{c}\text { compressor unit } \\
\text { displacement } \\
\left(\mathrm{Nm}^{3} / \mathrm{h}\right)\end{array}$ \\
\hline 400 & 15 & 1300 \\
\hline
\end{tabular}

\subsection{Model result analysis}

\subsubsection{Optimal capacity Configuration and economic analysis}

Bring the above-mentioned wind and solar resource data and equipment parameter data into the capacity optimization model established in this paper. Based on MATLAB programming, using quantum particle swarm algorithm to solve. Set the number of particles to 200 , the number of iterations to 500 , and run on the server for 1 hour and 58 minutes. The server is configured with an Intel Xeon E5 processor with $128 \mathrm{~GB}$ of storage. The optimal target value convergence process of the quantum particle swarm is shown in Fig.7.

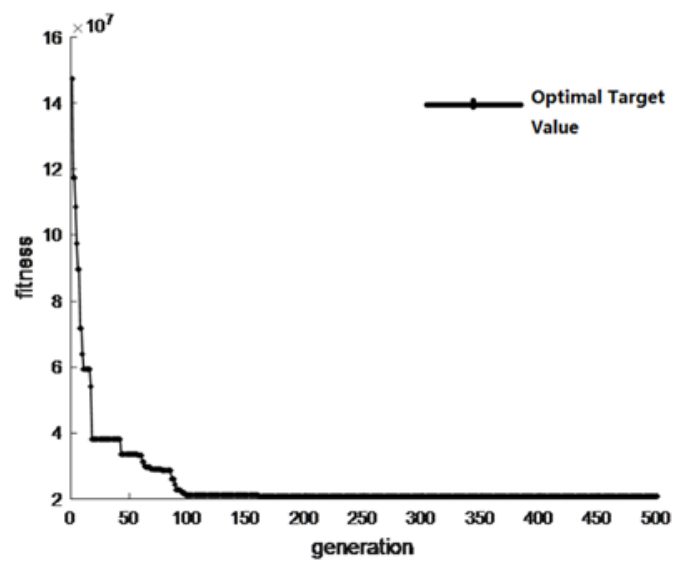

Fig.7. The convergence process of the optimal objective value of QPSO

It can be seen from Figure 7 that the target value shows a downward trend. The reaction particles are constantly searching for the optimal solution and converge very quickly. They have basically converged in the first 100 iterations, but the particles are not stuck in the local optimal solution and he target value still declines after 200 iterations. It can be seen that the quantum particle swarm has both fast convergence capabilities and global optimization capabilities. The final optimal capacity configuration is shown in Table 8.

Table8. Optimal capacity configuration

\begin{tabular}{cccccccc}
\hline $\begin{array}{c}\text { wind } \\
\text { turbine } \\
(\text { set })\end{array}$ & $\begin{array}{c}\text { PV } \\
(\mathrm{KW})\end{array}$ & $\begin{array}{c}\text { energy } \\
\text { storage } \\
\text { power } \\
(\mathrm{KW})\end{array}$ & $\begin{array}{c}\text { energy } \\
\text { storage } \\
\text { capacity } \\
(\mathrm{KWh})\end{array}$ & $\begin{array}{c}\text { electrolyzer } \\
(\mathrm{set})\end{array}$ & $\begin{array}{c}\text { single } \\
\text { power } \\
(\mathrm{KW})\end{array}$ & $\begin{array}{c}\text { fuel } \\
\text { cell } \\
(\mathrm{KW})\end{array}$ & $\begin{array}{c}\text { inverter } \\
\text { efficiency } \\
(\%)\end{array}$ \\
\hline 18 & 0 & 6147 & 12294 & 4 & 5000 & 0 & 5 \\
\hline
\end{tabular}


It can be seen from Table 8 that in this system, under the current technical conditions, the photovoltaic capacity and the fuel cell capacity are both 0 , that is, the micro-grid system under the optimal capacity configuration is fanbattery storage-hydrogen production by electrolysis of water. The reason why the photovoltaic installed capacity is 0 is that the energy conversion efficiency of photovoltaic cells is low, generally about $15 \%$; the second is that the cost of photovoltaic panels is higher than that of wind turbines. The cost of the photovoltaic power generation system used in this paper is 6000 yuan / KW, while the cost of wind turbines is only 3,000 yuan $/ \mathrm{kW}$. The fuel cell installed capacity is 0 because the fuel cell power generation efficiency is low under current technical conditions, and the direct sale of hydrogen will achieve better economic benefits.

Figure 8 shows the economics of the project. The cumulative net present value of the project for 20 years of operation is 220 million yuan. The dynamic payback period of the project is about 4 years, and an annual income of more than 45 million yuan can be obtained. In addition, the project can pay about 28 million yuan in taxes every year, and generate about 12 million yuan in environmental protection income every year. Under the current technical conditions, the project has good economic efficiency.

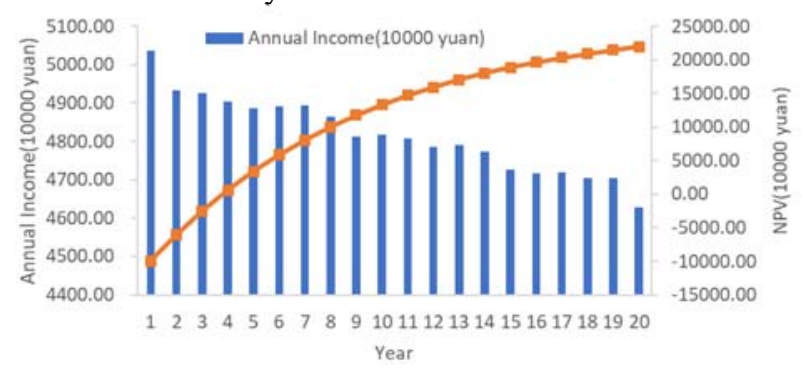

Fig.8. Annual income and annual net present value change of the project

It can be seen from Figure 9 that the hydrogen sales revenue of the system is between 74 million yuan and 83 million yuan, and the electricity sales revenue is between 38 million yuan and 43 million yuan, among which the electricity sales revenue is the electricity sales revenue to users and power grid.

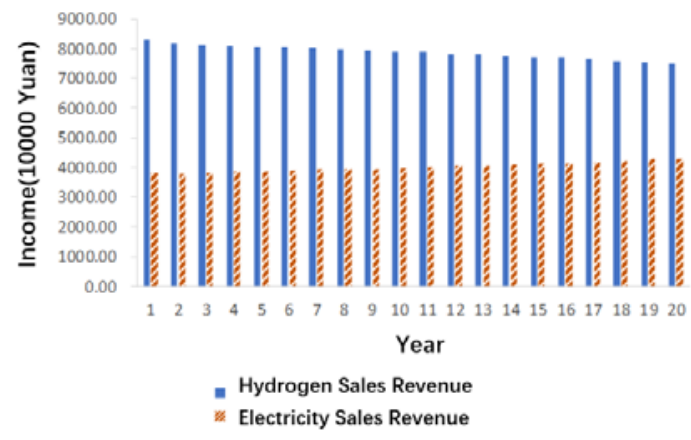

Fig.9. Annual sales of hydrogen and electricity sales revenue

\subsubsection{System operation index analysis}

(1) System power generation
As shown in Figure 10, the annual wind power generation of the system is maintained at about 1900MWh. This paper assumes that the user load increases year by year, and the average proportion of power purchase from the system to the grid is $4.9 \%$. With the continuous growth of user load, the system can maintain a high proportion of self-sufficiency, which shows that the system has high power supply reliability. The power purchase of the power grid increased from $70.97 \mathrm{MWh}$ in the first year to 129.66 $\mathrm{MWh}$ in the 20th year, and the power abandonment rate (i.e. the power selling rate to the power grid) decreased from $14.9 \%$ in the first year to $10.3 \%$ in the 20 th year, which indicates that the system can absorb the surplus power and reduce the impact of the system on the power grid through reasonable energy management strategy.

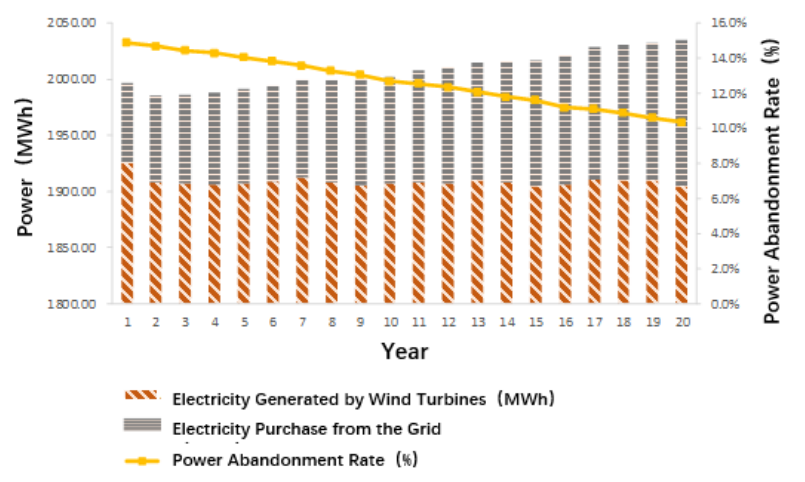

Fig.10. Annual power generation of the system

(2) Operation of energy storage system

As can be seen from Figure 11, the annual charge and discharge capacity of the battery increased from $8.60 \mathrm{MWh}$ in the first year to $9.42 \mathrm{MWh}$ in the 20 th year, the proportion of battery charge and discharge in the annual demand decreased from $16.3 \%$ in the first year to $12.3 \%$ in the 20th year, and the average annual state of charge decreased from $41.0 \%$ to $39.9 \%$. With the increase of annual power load, the energy storage system plays a good role in peak load regulation, which makes the power purchase and abandonment rate of power grid at a low level.

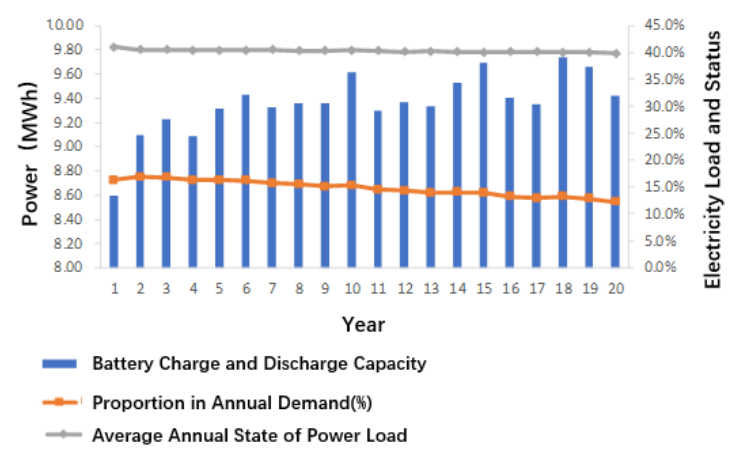

Fig.11. Annual operation of energy storage system

(3) Operation of electrolytic hydrogen production system

It can be seen from Figure 12 that the utilization rate of the electrolytic cell is high, always above $61 \%$.It is worth noting that in the previous solution process, the 
optimal installed capacity of the fuel cell is $0 \mathrm{KW}$, indicating that at this stage, compared with the hydrogen obtained by directly selling electrolyzed water, hydrogen fuel cell power generation has no configuration value in the micro-grid system.

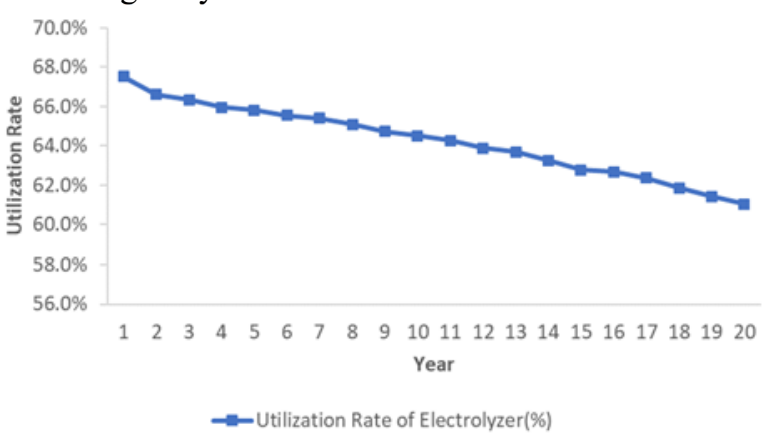

Fig.12. Electrolytic cell and fuel cell utilization

\subsection{Comparative analysis under different combination paths of micro-grid system}

By setting the definition domain of model decision variables, it is possible to study the capacity optimization configuration results and economy of the micro-grid system under different combined path modes. In the example of 4.2 , it is assumed that the micro-grid system

Table9. Optimal capacity configuration of micro-grid system involves Wind-PV generation, water electrolysis, Fuel cell power generation

\begin{tabular}{cccccc}
\hline $\begin{array}{c}\text { wind } \\
\text { turbine } \\
\text { (set) }\end{array}$ & photovoltaic $(\mathrm{KW})$ & $\begin{array}{c}\text { electrolyzer } \\
(\mathrm{set})\end{array}$ & $\begin{array}{c}\text { single power } \\
(\mathrm{KW})\end{array}$ & fuel cell $(\mathrm{KW})$ & $\begin{array}{c}\text { inverter efficiency } \\
(\%)\end{array}$ \\
\hline 28 & 0 & 9 & 5000 & 9545 & 9 \\
\hline
\end{tabular}

It can be seen from Figure 13 that the cumulative net present value of the system after 20 years of operation is 69 million yuan, and the dynamic payback period of the project is about 11 years, with a long payback period.

To analyze the reasons, in the absence of a battery energy storage system, in order to meet the energy shortage rate constraint, the installed capacity of wind power and fuel cells must be greatly increased to meet user load. At the same time, due to the volatility of wind resources, in the case of a substantial increase in wind turbine capacity, more electrolytic cells must be configured to absorb the surplus electricity, so as to meet the curtailment rate constraint. As the installed capacity of the main equipment has increased significantly, the cost of auxiliary equipment has also increased significantly, which greatly increases the cost of the project. In general, without battery energy storage equipment, the economic feasibility of the project is poor and the investment risk is high. includes wind power generation, photovoltaic power generation, battery energy storage, hydrogen production from electrolyzed water, and fuel cell power generation, that is, the upper limit of each component capacity is not 0 . Next, by setting the optimal upper limit of the installed capacity of different components to 0 , the optimal capacity allocation and the corresponding project economy of the micro-grid system under different combination paths are studied. It is worth noting that the optimization results in 4.2 show that the optimal installed capacity of fuel cell is $0 \mathrm{~kW}$, that is, when the upper limit of fuel cell capacity optimization is not set to 0 , the result of optimization search is still no fuel cell configuration.

\subsubsection{Combination path 1: Wind-PV generation + water electrolysis + Fuel cell power generation}

The upper limit of the installed capacity of the battery energy storage system is set to 0 , that is, the micro-grid system includes wind power generation, photovoltaic power generation, electrolytic hydrogen generation and fuel cell power generation systems. For other settings, refer to the previous papers to obtain the optimal capacity configuration, as shown in Table 9. 


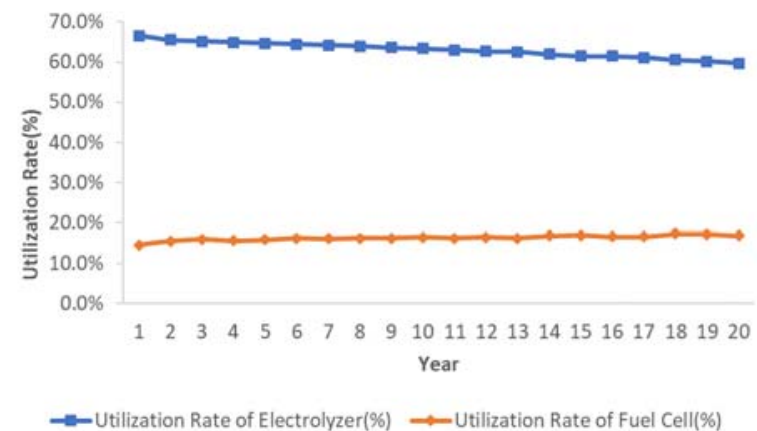

Fig.14. Electrolytic cell and fuel cell utilization

\subsubsection{Combination Path Two: Wind-PV generation + Electrochemical Energy Storage}

Set the upper limit of the installed capacity of the electrolysis hydrogen production system and the fuel cell power generation system to 0 , that is, consider the microgrid system including wind power generation, photovoltaic power generation, and battery energy storage. For other settings, refer to the previous papers. The algorithm optimization process is shown in Figure 15.

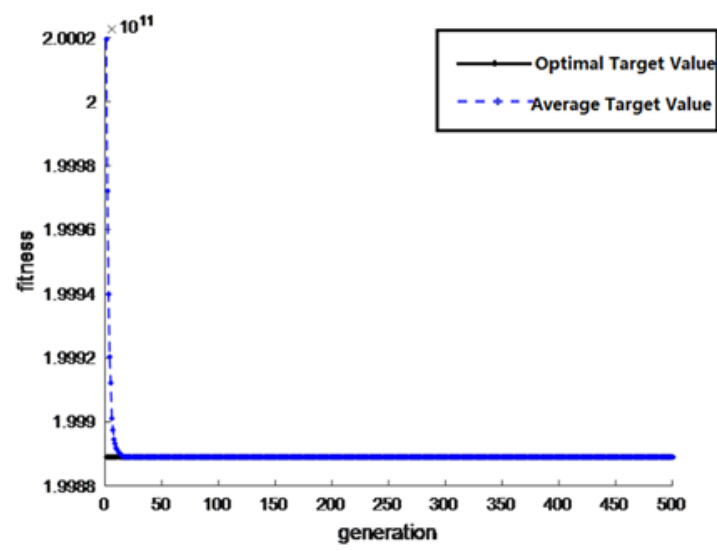

Fig.15. Quantum particle swarm optimal target value convergence process

As can be seen from the convergence process in Figure 15 , the algorithm has been converging rapidly in the early stage, and its fitness is maintained at $10^{11}$ level. The objective of this algorithm is to minimize the fitness. Generally, only when the fitness reaches $10^{11}$ level, the obtained solution has practical significance. Therefore, the system is not feasible without electrolytic hydrogen production system and fuel cell power generation system.

By looking at the optimization process, it is found that due to the two constraints of energy shortage rate and power abandonment rate, the solution obtained by the algorithm in the iterative process often triggers the penalty mechanism because it can not meet the two constraints, resulting in high fitness. In order to meet the demand of power consumption and reduce power abandonment, a large number of wind turbines, photovoltaic cells and batteries are deployed in the solution to meet the constraints, which leads to high investment cost, so the overall fitness can not be reduced.

\section{Conclusion}

In this paper, Wind-PV generation and energy storage systems are combined to establish a wind/photovoltaic/storage micro-grid system model, to study the optimization of capacity configuration and economics under different micro-grid composition paths, and use quantum particle swarm algorithm to solve the model.

This paper combines Wind-PV power generation and energy storage systems and establish a wind/photovoltaic/storage micro-grid system model to study the optimization of capacity allocation and economy under different micro-grid composition paths, and uses quantum particle swarm algorithm to solve the model. Taking the hourly data of a certain place in the north as an example, the optimal capacity allocation under two paths of Wind-PV generation + water electrolysis + fuel cell power generation system, Wind-PV generation + electrochemical energy storage system are studied and the economic analysis is carried out. In terms of model design, taking the maximum net present value of FCFF as the optimization objective, considering the impact of energy shortage rate and dynamic electricity price, different micro-grid system combinations are realized by setting the maximum optimization capacity of certain components in wind and solar power generation, battery energy storage, electrolytic water hydrogen production and fuel cell power generation to 0 . In terms of model calculation, the QPSO algorithm is used to randomly select points on the quantum cloud to avoid the possibility of local optimization. The model can provide a decision-making basis for selecting the optimal micro-grid composition according to the conditions of wind and solar resource in different regions and the status quo of technology and economy.

\section{Acknowledgement}

Project Supported by The National Key Research and Development Program (2018YFB1503101_05)

\section{References}

1. LIU Chang, ZHUO Jiankun et al. A Review on the Utilization of Energy Storage System for the Flexible and Safe Operation of Renewable Energy Microgrids [J]. Proceedings of the CSEE. 0258-8013 (2020) 010001-18

2. Amrollahi M H, Bathaee S M T. Techno-economic optimization of hybrid photovoltaic/wind generation together with energy storage system in a stand-alone micro-grid subjected to demand response[J]. Applied Energy. 2017,202:66-77.

3. Deng Dianyi, Li Wenyi, Chu Bingqing, et al. Reliability analysis of wind-photovoltaic-battery microgrids optimization configuration based on reliability constraints for distribution system[J]. ACTA Energiae Solaris Sinica, 2018,39(9):2439—2445.

4. Yang Tianmeng, Song Zhuoran, Lou Suhua, Wu Zhiming. Sizing of Hybrid Energy Storage System for 
Improving Wind Power Penetration [J]. Power System Technology. 2018,42(5):1488-1494(In Chinese).

5. Shao Zhifang, WU Jilan, Zhao Qiang. Evaluation and Simulation of Energy Interconnection[M]. Science Press.2018.4(In Chinese)

6. F.Grüger, O.Hoch, J.Hartmann, M.Robinius, D.Stolten. Optimized electrolyzer operation: Employing forecasts of wind energy availability, hydrogen demand, and electricity prices $(\mathrm{J})$. International Journal of Hydrogen Energy.2019, 44(5): 4387-4397.

7. H. Ishaq, I. Dincer, G.F.Naterer, Development and assessment of a solar, wind and hydrogen hybrid trigeneration system(J).International Journal of Hydrogen Energy. 2018, 43(52):23148-23160.

8. Men Xiangyang, Cao Jun, Wang Zesen, Du Wenjuan. Construction and Energy Storage Mode Analysis of Energy Interconnected Microgrid Multi-energy Complementary System[J]. Proceedings of the CSEE, 2018.38(19): 5727-5737(In Chinese).

9. Sanchez V M , Chavez-Ramirez A U, Duron-Torres S $\mathrm{M}$, et al. Techno-economical optimization based on swarm intelligence algorithm for a stand-alone windphotovoltaic-hydrogen power system at south-east region of Mexico[J]. International Journal of Hydrogen Energy.2014, 39(29):16646-16655.

10. Khiareddine A, Salah C B , Rekioua D, et al. Sizing methodology for hybrid photovoltaic /wind/ hydrogen/battery integrated to energy management strategy for pumping system[J]. Energy. 2018, 153.

11. Pablo G.-T., Luis M., Antonio G., et al. Optimized operation combining costs, efficiency and lifetime of a hybrid renewable energy system with energy storage by battery and hydrogen in grid-connected applications[J]. International Journal of Hydrogen Energy, 2016, vol.41:23132-23144.

12. Zhao Bo, Bao Kankan, Xu Zhicheng, et al. Optimal Sizing for Grid-connected PV-and-storge Microgrid Considering Demand Response(J). Proceeding of the CSEE, 2015, 35(21):5465-5474 (in Chinese).

13. Abla Khiareddine,Chokri Ben Salah,Djamila Rekioua,Mohamed Faouzi Mimouni. Sizing methodology for hybrid photovoltaic /wind/ hydrogen/battery integrated to energy management strategy for pumping system[J]. Energy,2018,153.

14. Maleki A, Askarzadeh A . Comparative study of artificial intelligence techniques for sizing of a hydrogen-based stand-alone photovoltaic/wind hybrid system[J]. International Journal of Hydrogen Energy, 2014, 39(19):9973-9984.

15. Wen J, Zheng Y, Donghan F. A review on reliability assessment for wind power[J].RENEWABLE \& SUSTAINABLE ENERGY REVIEWS.2009, 13(9):2485-2494.

16. Zhang Zheyuan, Wei Fanrong, Sui Quan, et al. Multistage power supply planning method for remote micro-networks in remote communities considering the interaction between economic growth and power supply [J]. Journal of China Electrical Engineering. 2018, 38(21): 6264-6275+6488.

17. Baghaee H R, Mirsalim M, Gharehpetian G B, et al. Reliability/cost-based multi-objective Pareto optimal design of stand-alone wind/PV/FC generation microgrid system[J]. Energy. 2016,115(1):1022-1041. 